${ }^{1}$ Mersin Üniversitesi Tıp Fakültesi, Patoloji AD, Mersin

e-posta:

ferahdaloglu@hotmail.com ORCID: 0000-0001-6506-9461

${ }^{2}$ Atatürk Üniversitesi Tıp Fakültesi, Patoloji AD, Erzurum e-posta:

elifpat@gmail.com

ORCID: 0000-0002-6660-3870

e-posta:

nsgursan@hotmail.com ORCID: 0000-0003-0030-7347

Atıf Için: Ferah TUNCEL, Kolon Poliplerinin Ayırıcı Tanısında Yeni Bir Yaklaşım; Stereoloji, Balıkesir Medical Journal, 2021;5(1):60-71

Başvuru Tarihi: 23.02.2021

Kabul Tarihi: 26.02.2021 Yayınlanma Tarihi: 28.02.2021

Sorumlu Yazar:

Ferah TUNCEL,

Mersin Üniversitesi Tıp Fakültesi, Patoloji AD, Mersin e-posta: ferahdaloglu@hotmail.com

\section{Kolon Poliplerinin Ayırıcı Tanısında Yeni Bir Yaklaşım; Stereoloji}

\author{
A New Approach in Differential Diagnosis of Colon Polyps; Stereology
}

\author{
Ferah TUNCEL ${ }^{1}$, Elif DEMIRCi ${ }^{2}$, Nesrin GÜRSAN ${ }^{3}$
}

Öz

Amaç: Bu çalışmanın amacı; neoplastik potansiyeli de olabilen kolon poliplerinin histopatolojik özelliklerine göre sınıflandığında tanı güçlüğü oluşturabilen olgular için tanıda kullanılabilecek stereoloji yönteminin değerini araştırmaktır.

Gereç ve Yöntemler: Bu çalışmaya 236 adet kolorektal polip olgusu dahil edilmiş ve olgular Dünya Sağlık Örgütü'nün 2010 yılı sınıflamasına göre histomorfolojik özellikleri göz önüne alınarak hiperplastik polip, serrated adenom, tübüler adenom, tübülövillöz adenom, villöz adenom şeklinde gruplara ayrılmıştır. Olguların stereolojik yöntemler ile ölçümleri yapılarak elde edilen veriler karşılaştırılmıştır.

Bulgular: Olgular cinsiyetlerine göre değerlendirildiğinde erkek cinsiyet ağırlıktaydı. Stereolojik ölçümler sonucu elde edilen veriler gruplar arasında karşılaştırıldığında birçok parametrede farklılıklar mevcuttu.

Sonuç: Poliplerin sınıflandırılmasında histopatolojik özellikler yanısıra stereolojik çalışmalar da kıymetlidir.

Anahtar Kelimeler: Stereoloji, kolon, polip, tanı, klinikopatolojik özellikler

\section{ABSTRACT}

Aim: The aim of this study is; to investigate the value of the stereology method that can be used in the diagnosis of colon polyps, which may also have neoplastic potential and have diagnostic difficulties based on histopathological classification.

Materials and Methods: In this study, 236 cases of colorectal polyps were included and according to the histomorphological features determined in the World Health Organization classification of 2010. The cases were grouped as hyperplastic polyps, serrated adenomas, tubular adenomas, tübülövillöz adenoma and villous adenoma. They were measured with the stereological methods and the data obtained were compared.

Results: When the cases were evaluated according to their gender, male gender was predominant. When the data obtained as a result of stereological measurements were compared between the groups, there were differences in many parameters.

Conclusion: In addition to histopathological features, stereological studies are also valuable in classifying polyps.

Keywords: Stereology, colon, polyp, diagnosis, clinicopathological features 
Polipler gastrointestinal sistemin her yerinde görülebilmekle birlikte, kalın barsaklarda, özellikle rektum ve sigmoid kolonda sık görülen ve çekuma doğru sıklıkları giderek azalan mukoza yüzeyinden lümene doğu çıkıntı yapacak şekilde uzanım gösteren doku kitlesidir $(1,2,3,4)$. Kendi içerisinde non neoplastik ve neoplastik polip olmak üzere iki ana grup halinde sınıflandırılır (1). Prevelansı \%20- 40 olarak bildirilmiştir (5). Son yıllara kadar neoplastik potansiyeli olmadığı düşünülen hiperplastik poliplerin de tanımlanan genetik mutasyonlar sonucunda adenokarsinom prekürsörü olabilecekleri öngörülmektedir (6). Adenomlar; adenokarsinomlara dönüşme potansiyelleri, boyutu, histolojik tip ve epitelyal displazi derecesine göre değişkenlik gösterir (1). Histomorfolojik kriterlere göre sınıflandırıldığında tanısal uyumsuzluklar olabileceği bilinmektedir $(7,8,9)$. Bu nedenle tanısal katkı sağlayabilecek ek yöntemlere pratikte ihtiyaç vardır.

Stereolojik yöntemler; gerçekte üç boyutlu olan canlı ya da cansız yapıların, iki boyutlu düzlemde elde edilen görüntülerinden yola çıkarak hacim, yüzey alanı, sayı ve uzunluk gibi birçok önemli sayısal değere ulaşabilmeyi sağlayan yöntemlerdir $(10,11,12)$.

Bu çalışmada 236 adet kolorektal polip olgusu stereolojik yöntemler ile ölçümleri yapılarak gruplar arasındaki farkııııların karşılaştırılması ve elde edilen verilerin tanıya katkısını araştırmak amaçlanmıştır.

\section{GEREÇ VE YÖNTEMLER}

Bu çalışmaya bir üniversite hastanesinde polip tanısı alan 236 olgu dahil edilmiştir. Hastalara ait arşiv dosyaları incelenerek, yaş, cinsiyet, polip lokalizasyonu, polibin pedinküle ya da sesil oluşu gibi klinik veriler kaydedilmiş ve olgular tekrar değerlendirilirken tanılar revize edilmiştir. Çalışmaya dahil edilen olgular tanılarına göre hiperplastik polip, serrated adenom, tübüler adenom, tübülövillöz adenom, villöz adenom şeklinde gruplara ayrılmış, stereolojik yöntemler ile ölçümleri yapılarak polibin tamamının kapladığı alan, glandların kapladığı alan, stromanın kapladığı alan, kriptlerin yüzey alanı, glandların lümen çapları, birim alan başına düşen glandüler epitel hücre sayısı belirlenmiştir. Bu çalışmada, alan parçalama metodu ile sayım hesaplaması yapılan tarafsız sayım çerçeveleri içeren özel bir yazılım içeren Stereo-Investigator (sürüm 9.0, Microbrightfield, Colchester, VT) kullanılmıştır (Resim 1).

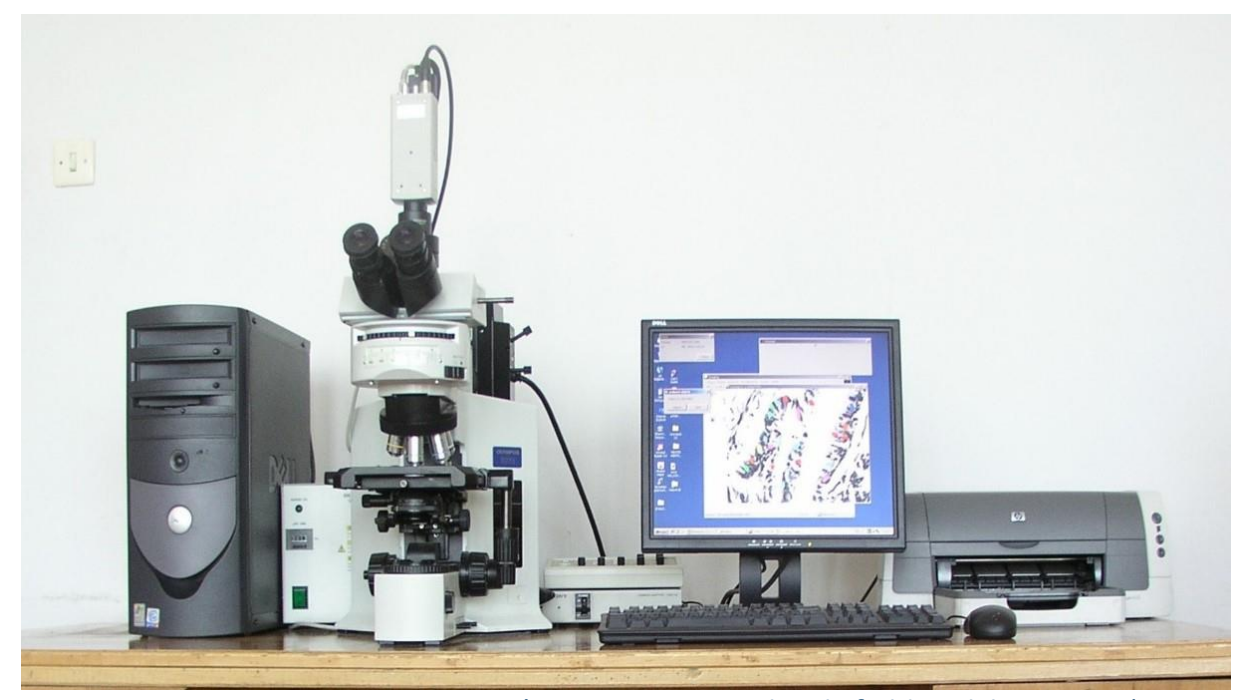

Resim 1. Stereo-Investigator (sürüm 9.0, Microbrightfield, Colchester, VT) 
Sözü edilen cihaz; kameralı bir mikroskop, mikroskop tablasını hareket ettiren motorize sistem ve bunların kullanımını kontrol eden yazılımı barındıran bir bilgisayardan oluşmaktadır (Resim 1).

Bu çalışmada stereolojik metodlardan olan "alan parçalama" ve "noktalı alan ile tarafsız sayım çerçevesi" kombinasyonu beraber kullanılmıştır. Çalışmada, Hemotoksilen-Eosin (H\&E) ile boyanan kesitler üzerinde ölçüm yapacağımız alanın (polip) dış hatları program yardımı ile çizildi. Ölçüm yapılacak alanlar belirlendikten sonra, alan parçalama kurallarına göre $x$ ve y ekseninde adım aralıkları belirlendi ve birbirinden belli adım aralıkları ile ayrılmış tarafsız sayım çerçeveleri rastgele bir açıyla bilgisayarda (kullanılan yazılım bu imkânı sağlamaktadır) kesit üzerine yerleştirildi. Böylelikle kesit üzerinde "Sistematik Rasgele Örnekleme" (SRÖ) ile 5 farklı alan belirlendi (Resim 2).

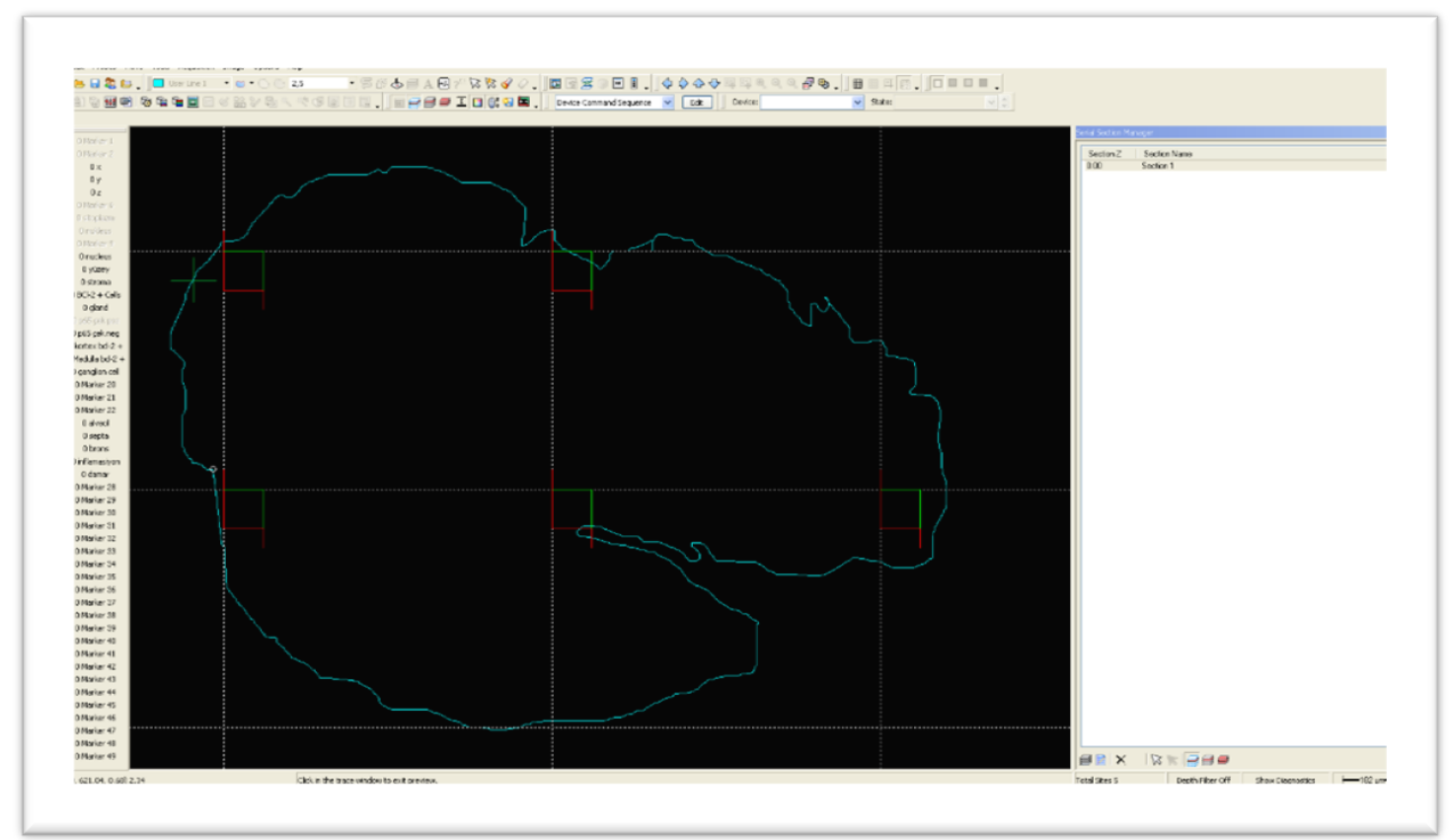

Resim 2. Stereo investigator programında alan parçalama işleminin uygulanması

Sonraki aşamalarda, tarafsız sayım çerçevesinin içine düşen gland epitel hücreleri nükleusları baz alınarak işaretlendi. Formül yardımıyla kesitlerin sayısal yoğunluk parametreleri yazılım tarafından otomatik olarak hesaplandı (13). Sy = TiT/(TSÇ x ÖAS). Formüldeki; Sy: "Sayısal Yoğunluk" TSÇ: "Tarafsız sayım çerçevesi" (XY) $\left(\mu \mathrm{m}^{2}\right)$, ÖAS:“Örneklenen Alan Sayısı” тіт: “Toplam İşaretlenen Tanecik” değerlerini temsil etmektedir.

\section{Kesitler Üzerinde Alan Ölçümü Hesaplanması}

Alan parçalama metoduna göre örneklenen alanlarda birbirinden eşit aralıklarla ayrılmış noktalardan oluşan sistematik nokta dizgelerini içeren noktalı alan cetveli rastgele bir açıyla kesit üzerine bırakıldı (Resim 3).

Daha sonraki aşamalarda ise, kript yüzey epiteli, gland epiteli ve stroma üzerine gelen noktalar farklı renkte işaretleyiciler ile işaretlendi ve aşağıda belirttiğimiz formüle göre ilgili alanlar özel yazılım tarafından otomatik olarak ölçülüp değerler kaydedildi,

$$
A=\frac{1}{a s f} \times a(p) \times P(Y i)
$$




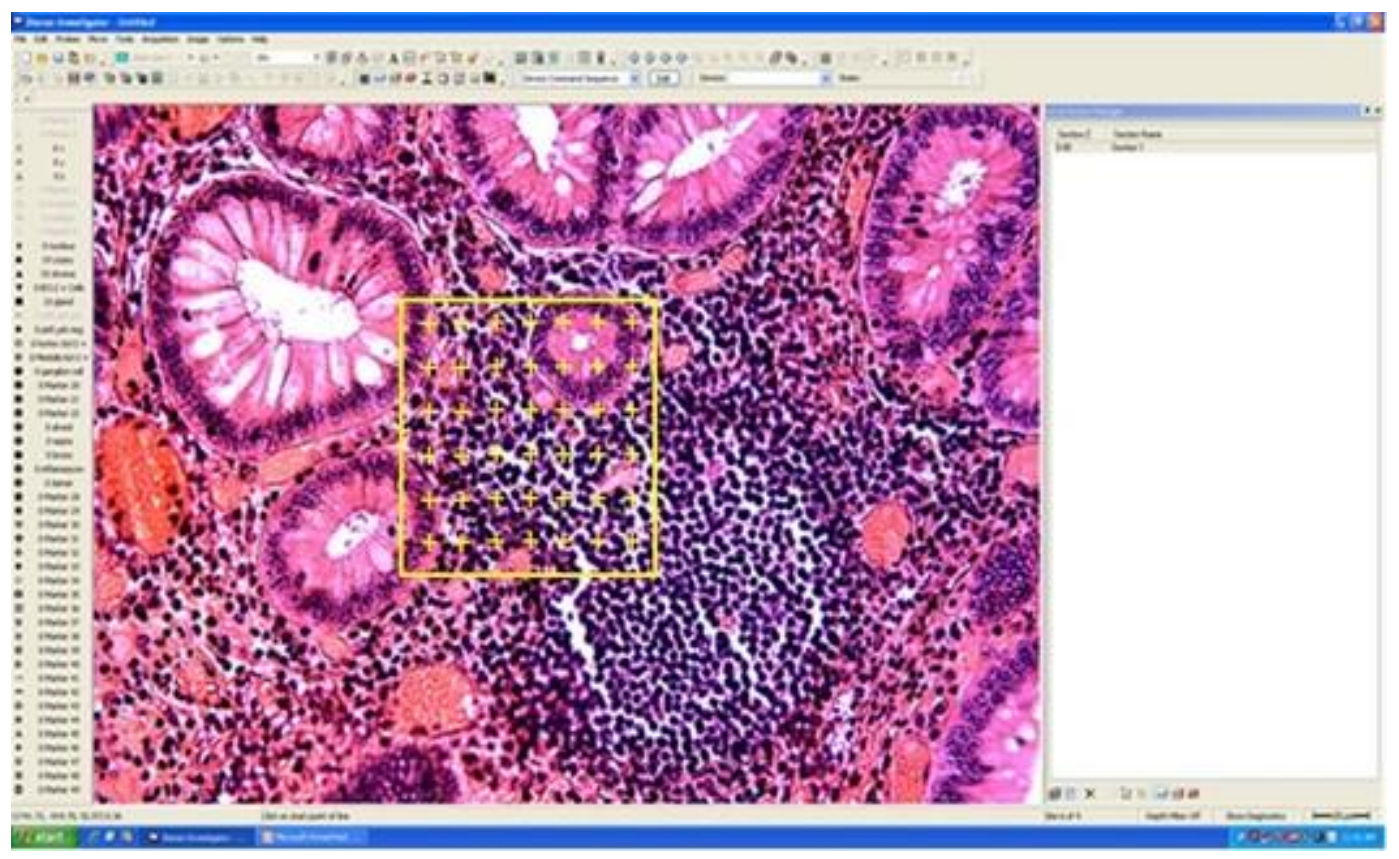

Resim 3. Kolon polibine ait kesit üzerine noktalı alan cetvelinin uygulanması

$\mathrm{Bu}$ formüldeki ifadeler; A: hesaplanan alan, asf: örneklenen alan fraksiyonu, a(p) nokta ile ilişkilendirilen alan, $\mathrm{P}(\mathrm{Yi})$ işaretlenen nokta sayısıdır (14). Tüm gruplardaki diğer preparat kesitleri için de aynı işlemler uygulandı.

\section{Kesitler Üzerinde İzlenen Gland Lümen Çaplarının Hesaplanması}

Çalışma grubumuzu oluşturan olgulara ait kesitlerde örneklenen alanlar içerisinde izlenen gland yapıları belirlendi. Stereo-Investigator programında yer alan "hızlı ölçüm çizgisi” ile gland lümenleri en geniş yer baz alınarak ölçüldü ve kaydedildi (Resim 4).

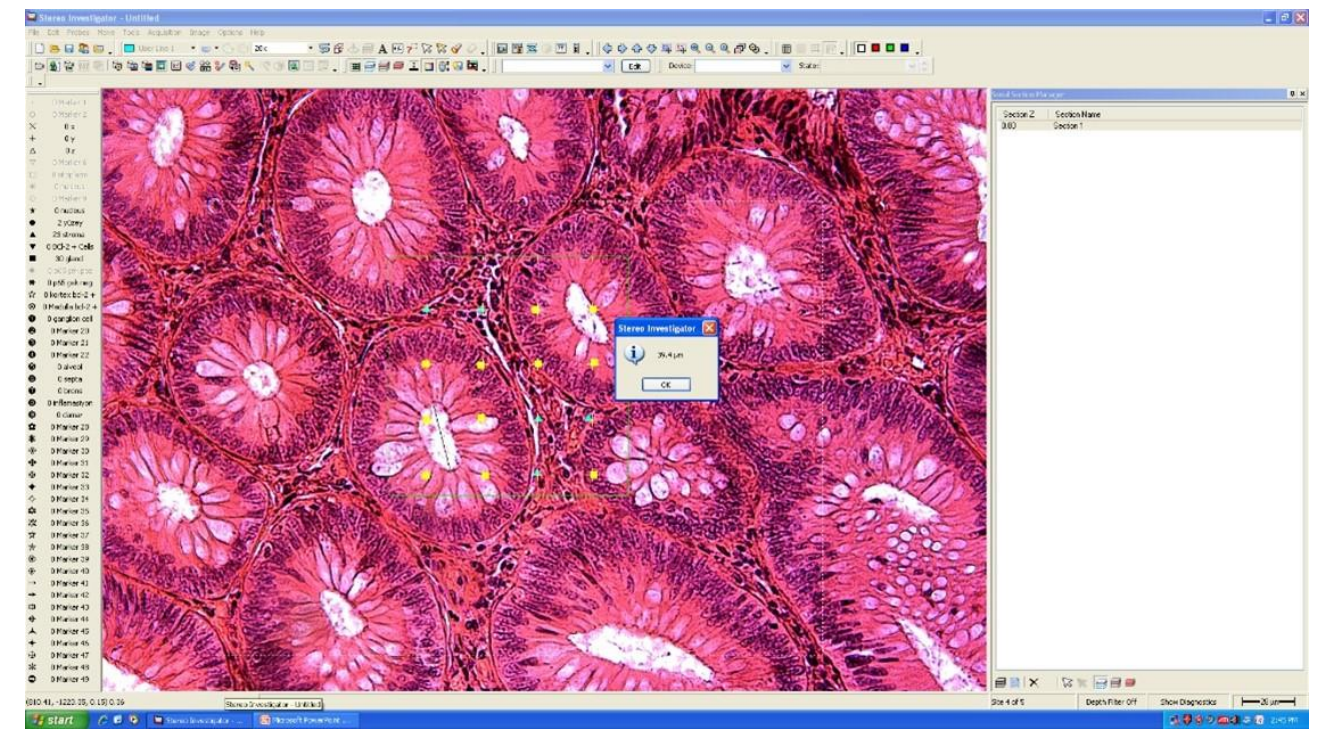

Resim 4. Kolon polibine ait kesit üzerinde belirlenen alan içerisindeki glandların lümen çaplarının "hızlı ölçüm çizgisi" ile ölçülmesi 


\section{Etik Kurul}

Çalışmaya ait etik kurul onayı, Atatürk Üniversitesi Tıp Fakültesi Etik Kurulu'nun 28.06.2012 tarih 4 nolu oturum ve 32 sayılı kararı, Cerrahi Tıp Bilimleri Bölüm Kurulu'nun 26.06.2012 tarih 4 nolu oturum ve 17 sayılı kararı ile onaylanmıştır. Çalışmanın yönetilmesinde ve makalenin hazırlanmasında araştırma ve yayın etiğine uyulmuştur.

\section{İstatistiksel Analiz}

Olgularımız tanılarına göre beş farklı grup halinde sınflandıııldı ve tanılar ile polibin tamamının kapladığı alan, kriptlerin yüzey alanı, glandların kapladığı alan, stromanın kapladığı alan, glandların lümen çapları, birim alan başına düşen glandüler epitel hücre sayısı arasında ilişki olup olmadığını araştırmak için SPSS 21.0 for Windows (SPSS Inc. Chicago. IL. USA) paket programı kullanıldı. Grupların ortalama değerlerini karşılaştırmak için Ki-Kare testi kullanıldı. Değişkenlerimiz normal dağılıma uymadığından gruplar arası farklılıkların araştırılması için Kruskall Wallis testi kullanıldı. Aradaki farkın hangi değişkenden kaynaklandığını belirlemek için Bonferoni düzeltmasi ile Mann-Whitney U testi kullanıldı. Yanılma düzeyi olarak 0.05 değeri seçildi. Bu değere eşit ya da küçük p değerleri için "istatistiksel olarak önemli (anlamlı) farklılığın / ilişsinin olduğu" yorumu yapıldı.

\section{BULGULAR}

Bu çalışmaya polip tanısı alan 236 olgu dahil edildi. Çalışma için hedeflenen her gruptaki olgu sayısı 50 olmasına rağmen mevcut arşivimizde bulunan villöz adenom tanısı alan olgu sayısı 16 ile kısıtlı kaldı. Diğer gruplarda hedeflenen olgu sayısına ulaşıldı.

Olgular cinsiyetlerine göre değerlendirildiğinde erkek cinsiyet ağırlıktaydı ve bu farklılık istatistiksel olarak anlamlıydı ( $p=0.03$ ). Olgular cinsiyetleri yanısıra tanılarına göre değerlendirildiğinde ise villöz adenom tanısı alan olgular haricindeki tüm gruplarda erkek cinsiyet hakimdi ( $p=0.03)$ (tablo 1$)$.

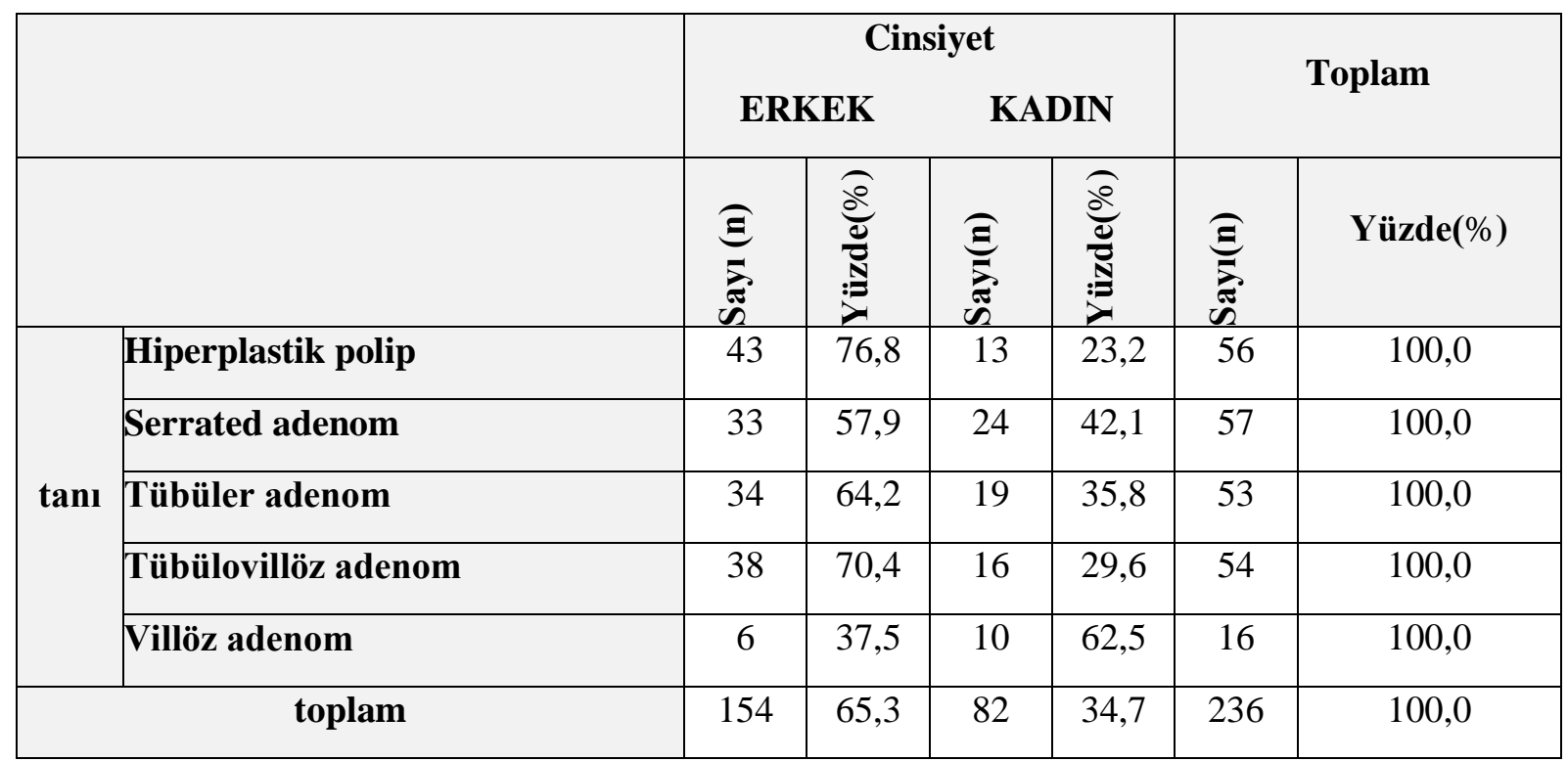

Tablo 1. Polip olgularında tanıların cinsiyete göre dağılımı 
Olgularda en küçük yaş 19 en büyük yaş 88 olup, ortalama yaş 59,58 $( \pm 13,86)$ idi. Tanıları ve tanı aldığı andaki yaşları karşılaştıııldığında poliplerin \%31,8 (n=75/236) ile en sık 60-69 yaş arasında görüldüğü izlendi. Tanı ile yaş aralığı karşılaştırıldığında dikkat çeken nokta; tüm polipler ileri yaşlarda daha sık görülmekte iken tübüler adenom olguları nisbeten daha genç yaşlarda (50- 59 yaş) sıklıkla görülmekteydi ( $n=18 / 53, \% 34)$ $(p=0.00)$ (grafik 1).

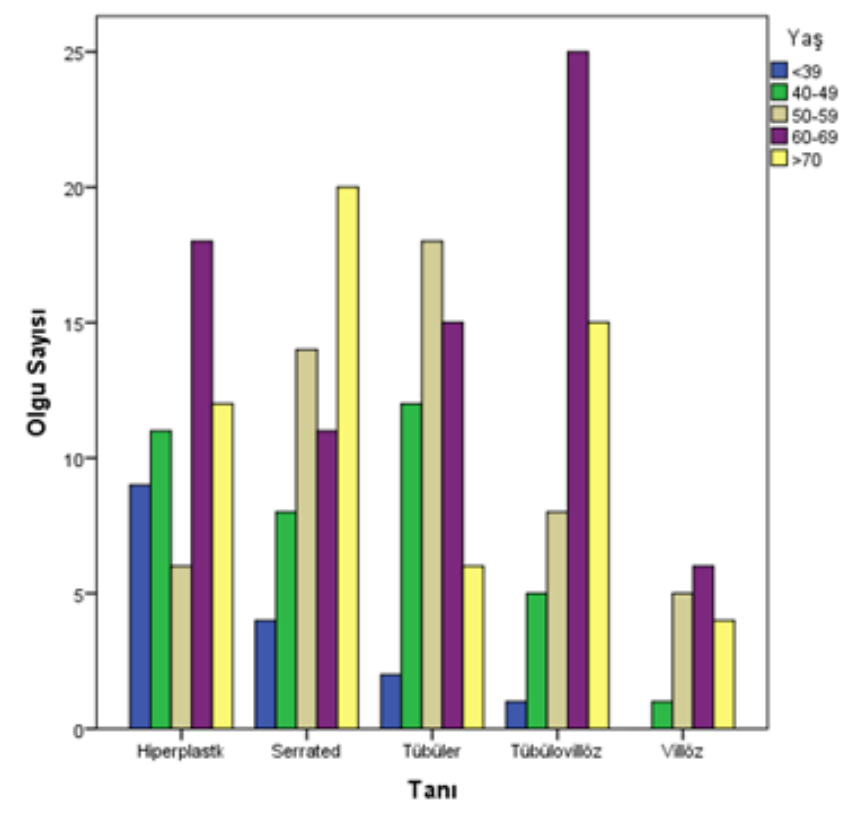

Grafik 1. Tanıların yașa göre dağılımı

Yerleşim yerleri incelendiğinde tüm poliplerin \%69,2'si(n=162) rektosigmid bölgede yerleşim gösterirken, \%13,2'si(n=31) transvers kolonda bulunmaktaydı. Ancak tanı ile yerleşim yerleri karşılaştırıldığında elde edilen veriler istatistiksel olarak anlamlı değildi ( $p=0.77)$.

Gruplar ile poliplerin sesil/pedinküle olması durumu karşılaştırıldığında istatiksel olarak anlamlı farklılıklar mevcuttu ( $p=0.00$ ). Hiperplastik polip, tübülovillöz adenom, villöz adenom tanılı gruplarda olguların çoğu sesil iken serrated adenom ve tübüler adenom tanılı gruplardaki olgularda polip yapılarının genellikle pedinküle olduğu dikkat çekti (tablo 2 ).

\begin{tabular}{|l|c|c|c|c|c|c|}
\hline \multirow{2}{*}{} & \multicolumn{4}{|c|}{ Pedinküle } & \multicolumn{2}{c|}{ Toplam } \\
\cline { 2 - 7 } & Sayı & Yüzde \% & Sayı & Yüzde\% & Sayı & Yüzde\% \\
\hline Hiperplastik & 12 & 21,4 & 44 & 78,6 & 56 & 100 \\
\hline Serrated & 37 & 66,1 & 19 & 33,9 & 56 & 100 \\
\hline Tübüler & 31 & 60,8 & 20 & 39,2 & 51 & 100 \\
\hline Tübülovillöz & 18 & 34,6 & 34 & 65,4 & 52 & 100 \\
\hline Villöz & 3 & 18,8 & 13 & 81,3 & 16 & 100 \\
\hline \multicolumn{1}{|c|}{ Toplam } & 101 & 43,7 & 130 & 56,3 & 231 & 100 \\
\hline
\end{tabular}

Tablo 2. Poliplerin pedniküle /sesil oluşuna göre dağılımı 


\section{Stereolojik Ölçüm Sonucunda Elde Edilen Bulgular}

Olguların stereolojik ölçümleri sonucunda elde edilen veriler aşağıda sunulmuştur (tablo 3). Stereolojik ölçümler sonucu elde edilen veriler gruplar arasında karşılaştırldığında polibin toplam alan ölçüm sonuçlarında, anlamlı farklılıklar mevcuttu $(p=0.00, K W=53,75)$ Benzer şekilde polibin yüzey alanı ölçüm sonuçları da farklııılar içermekteydi ( $p=0.00, \mathrm{KW}=80,13)$. Glandların kapladığı alan $(\mathrm{p}=0.00, \mathrm{KW}=33.88)$, stromanın kapladığı alan ( $p=0.00, K W=26.22)$, alan başına düşen gland epitel hücresi sayısı $(p=0.01,12.99)$, ortalama gland lümen çapı ( $p=0.00, \mathrm{KW}=25.91$ ) gibi diğer parametrelerde de gruplar arasında farklılıklar mevcuttu ve bu farklılıklar istatiksel olarak anlamlıydı. Gruplar kendi içlerinde incelendiğinde serrated adenom tanılı grup ile tübüler adenom tanılı grupta benzer şekilde polibin toplam alanının büyük kısmını glandlar oluştururken, hiperplastik polip ve tübülovillöz adenom tanılı grupta stroma oluşturmaktaydı. Villöz adenom tanılı grupta ise diğer tüm gruplardan farklı olarak toplam alanın büyük bir kısmını belirgin bir fark ile yüzey alanı oluşturmaktaydı.

\begin{tabular}{|c|c|c|c|c|c|c|}
\hline & 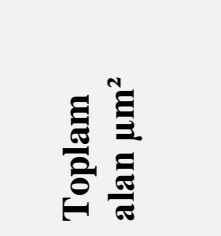 & 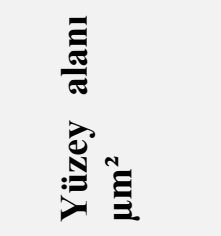 & 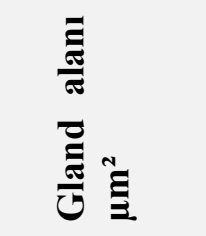 & 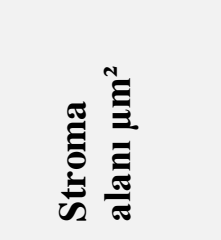 & 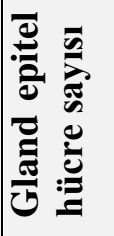 & 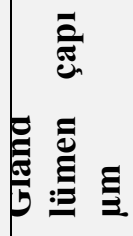 \\
\hline Hierplastik polip & 3641020,80 & 566920,13 & 1309390,64 & 1462493,36 & 26,9 & 66,49 \\
\hline Serrated adenom & 4685819,81 & 732993,52 & 1716265,89 & 1478079,58 & 26,8 & 61,72 \\
\hline Tübüler adenom & 8998102,45 & 1287743,65 & 3460058,29 & 2336605,09 & 46,2 & 72,49 \\
\hline Tübülovillöz adenom & 35380935,37 & 8432950,88 & 6999645,79 & 11068707,37 & 27,2 & 79,85 \\
\hline Villöz adenom & 53127130,63 & 31445738,87 & 8548080,53 & 8799076,81 & 26,8 & 87,51 \\
\hline
\end{tabular}

Tablo 3. Tanılara göre stereolojik ölçümlerden elde edilen verilerin ortalama değerlerinin karşılaştırılması

Alan başına düşen gland epitel hücresi sayıları incelediğinde hiperplastik polip $(n=26.9)$ ve serrated adenom ( $n=26.8$ ) tanılı grupta benzer sayılara ulaşıldı. Tübüler adenom tanılı grupta en yüksek gland epitel hücresi sayısı( $n=46.2)$ izlenirken, tübülovillöz adenom $(n=27.2)$ ve villöz adenom(n=26.8) tanılı gruplarda beklenenin aksine düşük değerlere ulaşıldı ( $P=0.01, \mathrm{KW}=12.99)$.

Gland lümen genişlikleri incelendiğinde en düşük değerler serrated adenom (61.72 $\mu \mathrm{m})$ ve hiperplastik polip $(66.49 \mu \mathrm{m})$ tanılı gruplarda ölçülürken en yüksek değerler villöz adenom (87.51 $\mu \mathrm{m})$ tanılı grupta kaydedildi. Sonuçlar istatistksel olarak anlamlı idi $(p=0.00, \mathrm{KW}=25.91)$.

\section{TARTIŞMA}

Kolorektal polipler; asemptomatik kişilerde \%20-40 prevelans ile görülen lezyonlardır (5). Klinik önemi; özellikle adenomatöz poliplerin kolorektal kanserler için neoplastik öncülleri olarak rol almalarından kaynaklanmaktadır $(15,16)$. Klinik, histolojik, moleküler çalışmalar kolon kanserlerinin esas olarak adenomatöz poliplerden orijin aldığını vurgulamaktadırlar (17). Adenomların sayısı, boyutu, histolojik tanısı, kolondaki lokalizasyonu gibi parametrelerin kolon kanseri gelişiminde önemli faktörler oldukları bilinmektedir (18-20). 
Liu H ve ark (21) yaptığı bir çalışmada 5973 asemptomatik kişide yapılan kolonoskopi sonrasında 971 $(\% 16,3)$ kişide kolon polibi tespit edildi ve kolon polibi izlenen hastaların 613'ü erkek iken 358 tanesi kadın cinsiyetteydi. Aslan F ve arkadaşlarının 187 hastayı kapsayan çalışmalarında da hastaların büyük çoğunluğu erkekti ( $n=116, \% 62)$ ve kadınlar azınlıktaydı ( $n=71, \% 38)$ (3). Yarıkkaya E ve arkadaşları da 123 hastayı kapsayan çalışmalarında hastalarının büyük çoğunluğunun erkek olduğunu bildirirlerken $(n=78, \% 63,4)$ kadınlar azınlıktaydı ( $n=45, \% 36.6)$. Ayrıca cinsiyet ayrımı gözetilmeden tüm hastaların 25 inde $(\% 20,3)$ iki ya da daha fazla polibin birlikte görüldüğünü de bildirmişlerdir (4). Bizim elde ettiğimiz verilerde de kolon poliplerinin cinsiyete göre dağılımına bakıldığında literatür ile uyumlu bir şekilde erkek cinsiyet fazla idi. Kolon polibi tanısı almış 236 olgumuzun \%65,3’ü ( $n=154 / 236)$ erkek iken \%34,72si ( $n=82 / 236)$ kadın idi $(p=0.03)$.

Pandergrass ve arkadaşlarının 3558 otopsi olgusu üzerinde yaptıkları çalışmada ise genç erişkinler ile (20-49 yaş) 50-89 yaş arasındaki olgular arasında kolonik adenomların bulunma sıklığı, lokalizasyonu, sayısı, olguların cinsiyeti gibi değişkenlerdeki farklılıkları incelemişlerdir (22). Bulgularında üçüncü dekadda kolorektal adenom prevelansını \%1,72 olarak izlerken dokuzuncu dekadda ise \%12,0 olarak bildirilmiştir. Bizim olgularımızın yaşa göre dağılımları incelendiğinde ortalama yaş 59,58 $( \pm 13,86)$ iken poliplerin $\% 31,8(n=75 / 236)$ ile en sık 60-69 yaş arasında görüldüğü izlendi $(p=0.00)$.

Kolon poliplerinin lokalizasyonları değerlendirildiğinde olguların büyük bir çoğunluğunun distal kolon yerleşimli olduğu tespit edilmiştir. Liu H ve ark (21) olgularının \%58,6'sının distal kolon yerleşimli olduğunu bildirmektedirler. Bizim olgularmızın yerleşim yerleri incelendiğinde tüm poliplerin \%69,2'si(n=162) rektosigmid bölgede yerleşim gösterirken \%13,2'si(n=31) transvers kolonda bulunmaktaydı. Ancak tanı ile yerleşim yerleri karşılaştırıldığında elde edilen veriler istatistiksel olarak anlamlı değildi ( $p=0.77)$.

Terry ve arkadaşları 190 kolorektal adenomatöz polip olgusu üzerinde iki farklı şekilde çalışmışlardır. Birincisinde aynı patolog tarafından 10 yıl ara ile aynı olgular değerlendirilmiş (intraobserver uyum) ve tanılar arasındaki uyum kullanılan bir skala (Kappa) yardımı ile belirlenmişir. Skalada sonuçlar "mükemmele yakın, neredeyse tam, orta, makul, az ve zayıf" şeklinde değerlendirilmiştir. Aynı patoloğun 10 yıl ara ile aynı olgulara koyduğu tanıların uyumu bu skalaya göre "makul" olarak yorumlanmışken çalışmanın ikinci kısmında iki farklı patolog aynı olguları eş zamanlı değerlendirmiş (interobserver uyum) ve ikisin verdiği tanılar arasındaki uyum sonuçları "orta" olarak yorumlanmıştır (8).

Bu çalışmalar sonucunda kolorektal polip olgularının tanısal sınıflamasında histomorfolojik kriterler esas alınmakla birlikte tanısal karmaşaya neden olabilecek olguların ayrımında daha objekif veriler sağlayabilecek ek yöntemlerin katkısı olabileceği düşünülebilir. Gerçekte üç boyutlu olan canlı ya da cansız yapıların, iki boyutlu düzlemde elde edilen görüntülerinden yola çıkarak hacim, yüzey alanı, sayı ve uzunluk gibi birçok önemli sayısal değere ulaşabilmeyi sağlayan stereolojik yöntemlerin kullanımı bu ara vakalarda kıymetli olabilir. $(9,10,11)$.

Literatürde birçok alanda yapılmış stereolojik çalışma yer almasına rağmen kolorektal polipler üzerinde yapılmış kısıtlı sayıda çalışma mevcuttu. 1981 yılında Elias H ve ark (23 ) yaptıkları çalışmada kolonik adenomların stereolojik yönemler ile yüzey alanı, polip hacmi, alan başına düşen epitel hücresi sayısını ölçerek 
buldukları verileri normal kolonik mukoza ve var ise polibin pedinkülünü örten mukozası ile karşılaştırdılar. Toplam 20 olgu üzerinde yapılan bu çalışma sonucunda polibin yüzey alanının normal mukoza ile kıyaslandığında, küçük çaplı poliplerde görülen artış 5,8 kat ile sınırlı iken büyük çaplı poliplerde bu artış 235 kata kadar çıkmaktaydı.

Bu çaılşmada alan başına düşen epitel hücresi sayısı da değerlendirildi ve normal kolonik mukoza ile kıyaslandığında poliplerde alan başına düşen epitel hücresi sayısında 12-370 kat artış tespit edildi. Pedinküle poliplerde polip ile pedinkül arasındaki yapılan karşılaştırmada alan başına düşen epitel hücresi sayısında küçük çaplı poliplerde pedinküle oranla 11 kat artış tespit ediliken polip çapı arttıkça bu oranın 468 kata kadar artığı bildirildi (23).

Aynı çalışmada karsinomların adenomatöz poliplerden orijin aldığı vurgulanırken bunun nedeninin poliplerin artmış yüzey alanı nedeni ile intestinal içerik içerisinde bulunan karsinojenlere artmış maruziyetinin neden olabileceği öne sürülmekteydi (23).

Biz çalışmamızda polipler ile normal kolonik mukoza arasında karşılaştırma yapmadık. Ancak olguları tanılarına göre gruplara ayırıp elde ettiğimiz stereolojik verileri gruplar arasında karşılaştırdık. Gruplar kendi içlerinde incelendiğinde serrated adenom tanılı grup ile tübüler adenom tanılı grupta sterolojik ölçümler sonucunda elde edilen veriler birbirlerine yakındı.

Pesce M.C ve ark (24) multiple polipozisli bir vakada 14 adet adenomatöz polip üzerinde stereolojik çalışma yaparak, adenomatöz poliplerde artan hacmin glandüler epitelin kapladığı alan ve yüzey epitelinin kapladığı alanın her ikisinde birden artışı ile orantılı olduğunu öne sürmüştür. Bu bulgular Lane ve Lev'in (25) adenomatöz poliplerde hem yüzey alanında hem de glandüler epitelin kapladığı alanda artış olduğunu bildirdiği çalışma ile uyumlu idi. Bizim çalışmamızda villöz adenom grubu ile hiperplastik polip grubu kıyaslandığında polibin toplam alanındaki belirgin artış vardı. Ancak villöz adenom grubundaki olguların yüzey alanı ortalama değerlerinde hiperplastik polip grubundaki olgulara göre 55,4 katlık bir artış izlenirken, glandüler epitelin kapladığı alanın ortalama değerlerinde yalnızca 6,5 katlık bir artış mevcuttu. Bu bulgularla villöz adenomlu olgularda artan toplam polip alanının önemli bir kısmını Pesce M.C ve ark (24) bulgularına tezat oluşturacak şekilde yüzey alanındaki artışın neden olduğu görülmekteydi.

Meijer G.A ve ark (26) 59 kolorektal adenom olgusunun displastik epitelinde yapısal değişiklikleri değerlendiren stereolojik çalışmada olguları öncelikle hafif displazi, orta derecede displazi ve yüksek derecede displazi bulguları içeren üç grup halinde sınıflamış ve gland iç yüzeyi, gland dış yüzeyi ve gland lümen uzunluğu ile ilgili verilerin anlamlı farklılıklar içerdiğini bildirerek kolorektal adenomların sınıflanmasında stereolojik tekniklerin faydalı olabileceğini vurgulamışlardır. Biz de olgularımızdaki ortalama gland lümen çaplarını "hızlı ölçüm çizgisi” yardımı ile belirledik ve gland lümen çaplarının ortalama değerlerini en yüksek olarak villöz adenom grubunda izlerken azalarak sırasıyla tübülovillöz adenom, tübüler adenom, hiperplastik polip ve serrated adenom grubu takip etmekteydi. Gruplar arasındaki fark anlamlı bulundu ( $p=0.00, K W=25.91)$. 
Stereoloji görüldüğü üzere alan, hacim, uzunluk, partikül sayısı gibi birçok kantitatif verinin elde edilmesi için kullanılabilen önemli bir metottur. Biz çalışmamızda kullandı̆̆ımız yöntem ile elde ettiğimiz kantitaif veriler nedeniyle stereolojik metotların tanıya katkı sağlayarak, prekanseröz olguların öngörülmesinde faydalı olacağı kanısına vardık.

Bu makale; 18.Uluslararası Doğu Akdeniz Aile Hekimliği Kongresi DAAHK 2019'da sözlü bildiri olarak sunulmuştur.

\section{TEŞEKKÜR}

Çalışmanın istatistiksel analizlerini yapan Dr. Aysun Aras'a teşekkür ederiz.

\section{KAYNAKLAR}

1. Kumar W, Abbas AK, Fausto N. Robbins and Cotran Pathologic Basis of Disease. Çeviri: Sav A, Özdamar Ş.Ü. Hastalığın Patolojik Temeli. Ankara: Güneş Tıp Kitapevleri Ltd Şti, 2009:797-875.

2. Eminler AT, Sakallı M, Kader Irak K, Ayyıldız T, Keskin M, Gülten iY ve ark. Gastroenteroloji ünitemizdeki kolonoskopik polipektomi sonuçlarımız, Akademik Gastroenteroloji Dergisi, 2011:10;112115.

3. Aslan F, Turan G, Altun E. Kuşakçıoğlu Ö. Kolorektal Kanser Hastalıkları. İstanbul: Nobel Tıp Kitabevleri Ltd.Şti. 2003: 1-239. Balıkesir ilindeki kolorektal polipektomi olgularının değerlendirilmesi, Balıkesir Medical Journal, 2017:1(3); 104-107.

4. Yarıkkaya E, Erdoğan Durmuş Ş, Demirtaş R. Kolorektal poliplerin klinikopatolojik özellikleri: Türkiye'nin Kuzey-Doğu Anadolu Bölgesinden retrospektif bir çalışma, Balıkesir Med. Journal, 2018:2(3); 178-184.

5. Suh S, Kang M, Kim MY, Chung HS, Kim SK, Hur KY. et al. Korean Type 2 Diabetes Patients have Multiple Adenomatous Polyps Compared to Non-diabetic Controls, J Korean Med Sci, 2011: 26(9); 1196-1200.

6. Odze RD, Noffsinger AE. Neoplastic Diseases of the small and large intestines. In Silverberg S.G (ed) Silverberg's Principles and Practice of Surgical Pathology and Cytopathology. China: Elsevier Inc, 2006: 1419-1464.

7. Bosman FT, Carnerio F, Hruban RH et al. WHO Classification of Tumours of the Digestive System. Lyon: IARCPress. 2010: 132-73.

8. Terry MB, Neugut A, Bostick A, Potter JD. Haile R, Fenoglio Preiser C. Reliability in the Classification of Advanced Colorectal Adenomas, Cancer Epidemiol Biomarkers Prev, 2002: 11; 660.

9. Gundersen HJG. Stereology of arbitrary particles. A review of unbiased number and size estimators and the presentation of some new ones in memory of William R Thomson, J Microsc, 1986: 143; 3-45. 
10. Cruz-Orive LM, Weibel ER. Recent stereological methods for cell biology: a brief survey, Cell Mol Psysiol, 1990: 2; 48-56.

11. Gundersen HJG, Bagger P, Bendtsen TF, Evans SM, Korbo L, Marcussen $N$ et al. The new stereological tools: Disector, fractionator, nucleator, and point sampled intercepts and their use in pathological research and diagnosis, APMIS, 1988a; 96; 857-881.

12. Canan S, Çolakoğlu S., Şahin B, Ünal B, Aslan H, Kaplan S, içinde: Cavalieri Prensibi ile Hacim Hesaplanması, Sinir Biliminde Temel Metotlar ve Stereoloji Kursu, Kurs notları 27 Ekim-6 Kasım 2006 Erzurum, sf. 1-27.

13. Unbiased Stereology, Three Dimensional Measurement in Microscopy, second edition, C.V. Howard \& M.G. Reed, bios scientific publishers, Oxford 1998, p. 63.

14. Jemal A, Siegel R, Ward E, Hao Y, Xu J, Murray T, et al. Cancer statistics, 2008, CA Cancer J Clin 2008:58; 71-96.

15. Fong TV, Chuah SK, Chiou SS, Chiu KW, Hsu CC, Chiu YC, et al. Correlation of the morphology and size of colonic polyps with their histology, Chang Gung Med J, 2003: 26; 339-343.

16. Cappell MS. Pathophysiology, clinical presentation, and management of colon cancer, Gastroenterol Clin North Am, 2008: 37;1-24.

17. Bond J. H. Polyp guideline: diagnosis, treatment, and surveillance for patients with nonfamilial colorectal polyps. The Practice Parameters Committee of the American College of Gastroenterology, Ann. Int. Med, 1993: 119; 836-843.

18. Atkin W. S., Morson B. C., Cuzick J. Long-term risk of colorectal cancer after excision of rectosigmoid adenomas. N. Engl. J. Med. 1992;326: 658-662.

19. Otchy DP, Ransohoff DF, Wolff BG, Weaver A, Ilstrup D, Carlson H et al. Metachronous colon cancer in persons who have had a large adenomatous polyp, Am. J. Gastroenterol, 1996:91; 448-454.

20. Noshirwani KC., van Stolk RU, Rybicki LA, Beck GJ. Adenoma size and number are predictive of adenoma recurrence: implications for surveillance colonoscopy. Gastrointest. Endosc, 2000: 51; 433 437.

21. Liu HH, Wu CM, Peng Y, Wu MS. Prevalence of advanced colonic polyps in asymptomatic, Chinese World J Gastroenterol, 2005:11(30);4731-4734.

22. Pandergrass CJ, Edelstein DL, Hylind LM, Phillips BT, Donahue Cl, Romans $\mathrm{K}$ et al. Occurrence of colorectal adenomas in younger adults: an epidemiologic necropsy study, Clin Gastroenterol Hepatol, 2008: 6(9);1011-1015.

23. Elias H, Hyde D, Mullens R, Lambert FC. Colonic adenomas: stereology and growth mechanisms, Diseases of the colon \& rectum, 1981: 24 (5);331-342. 
24. Pesce C. M, Colacino R. Relative growth of adenomatous polyps of the colon. Stereology and allometry of multiple polyposis, Virchows Arch A 1987: 412;151-154.

25. Lane N, Lev R. Observations on the origin of adenomatous epithelium of the colon. Serial section studies of minute polyps in familial polyposis, Cancer, 1963: 16;751-764.

26. Meijer GA, Fleege JC, Beak JP. Stereoloical assesment of architectural changes in dysplastic epithlium of colorectal adenomas, Pathol Res Pact, 1994:190(4);331-41. 